\title{
Plant Composition of Skuas Nests at Hennequin Point, King George Island, Antarctica*
}

\author{
Margéli Pereira de Albuquerque ${ }^{1,2}$, Filipe de Carvalho Victoria ${ }^{1,2}$, Adriano Luís Schünemann ${ }^{1,2}$, \\ Jair Putzke $^{2,3}$, Ricardo José Gunski ${ }^{1,2}$, Suzana Seibert ${ }^{2,4}$, Maria Virginia Petry ${ }^{2,4}$, \\ Antonio Batista Pereira ${ }^{1,2}$
}

${ }^{1}$ Federal University of Pampa, Campus São Gabriel, Rio Grande do Sul, Brazil; ${ }^{2}$ National Institute of Science and Technology Antarctic for Environmental Research, São Gabriel, Brazil; ${ }^{3}$ University of Santa Cruz do Sul, Santa Cruz do Sul, Brazi; ${ }^{4}$ University of Vale do Rio dos Sinos, São Leopoldo, Brazil.

Email: filipevictoria@unipampa.edu.br

Received January $19^{\text {th }}$, 2012; revised February $17^{\text {th }}$, 2012; accepted March $20^{\text {th }}$, 2012

\begin{abstract}
We investigate the plant composition in the Skuas nest at Hennequin Point, located in the Admiralty Bay Area, King George Island, Antarctica. Sample of 61 activity nests were analyzed. 21 plant and lichenized fungi species were found in the nest composition, being the mosses Sanionia uncinata (Hedw.) Loeske and Polytrichastrum alpinum (Hedw.) G. S. Smith the most frequent species found in the Skuas nests. Usnea antarctica Du Rietz was the most frequent lichen and the grass Deschampsia antarctica Desv was the most frequent flowering plant found in the nests. These results contribute for the environmental menagement of the Admiralty Bay area research activities.
\end{abstract}

Keywords: Plant Communities; Sea Bird Nests; Mosses; Lichen

\section{Introduction}

The Antarctic flora is composed mainly by mosses and lichens adapted to short summer periods and very low temperatures [1]. Such climatic conditions inhibit the reproductive cycle, limiting the occurrence of species, especially of flowering plants [2]. Deschampsia antarctica Desv. and Colobanthus quitensis Kunth. are the only native angiosperms growing in Antarctica, being restricted to Maritime Antarctica due to the longer daylight period, warmer temperatures and higher water availability in comparison to other parts of the Antarctic continent.

Skuas (Catharacta spp.) constitute a high and complex taxonomical group. At Antarctic Peninsula Catharacta lonnbergi and Catharacta maccormicki breed sympatrically, often constituting mixed pairs with fertile hybryds [3-5]. It is the most abundant flying bird at Admiralty Bay, King George Island, distributed in almost all icefree areas. The total numbers of breeding skuas increased by 349 pairs (293\%) from 1978/1979 to 2004/2005. It appears to be driven primarily by a tenfold increase in $C$. maccormicki pairs as well as a 95\% increase in mixed pairs. In contrast, C. lonnbergi pairs have declined by

*Research developed with support of Brazilian Environmental Ministry (MMA), National Research and Technology Council (CNPq), Interminitry Commission for Sea Resources (CIRM) and FAPERJ. These authors contributed equally to this work.
$40 \%$ during this same time period [6].

Skuas nests are located always on a flat area, made on a variety of substrates, the most usual being mosses and lichens, which is torn out and pressed down to form a scoop. One or several scoops can be made [7]. The nests are mostly found on habitats characterized by aabundant cover of the "moss-turf association". At Cierva Point, Antarctic Peninsula, the main nest components were Polytrichum alpestre Hoppe (= Polytrichastrum juniperinum Hedw.) and Deschampsia antarctica Desv though many mosses and lichens are found [8]. Therefore the plant species that compose the Skuas nests will be determined by the characteristics of the local habitat. In this context, the objective of the present study is to describe plant composition of Skuas nests at Hennequin Pont, King George Island, Antarctica.

In this study 61 activity nests were evaluated (Figure 1). They were located on mosses fields, rocks outcrops or, in some cases, on thawing channels.

\section{Materials and Methods}

During 2010/11 austral summer, a detailed mapping and characterization of plant composition of Skuas nests was carried out on Hennequin Point, eastern coast of Admiralty Bay, King George Island. The studied site comprises approximately $3.06 \mathrm{~km}^{2}$ of ice-free area, composed 


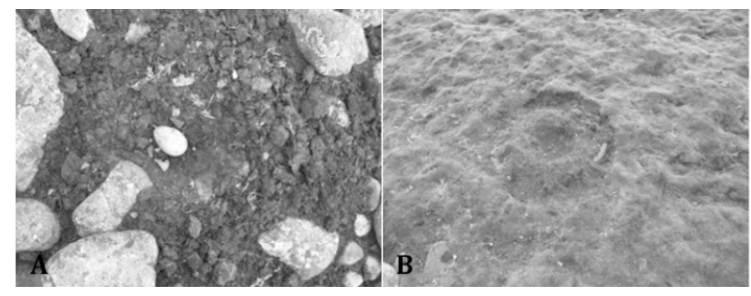

Figure 1. Example of Skuas nests sampled in Hennequin Point, admiralty bay, King George Island. (A) Active nest, with eggs; (B) Inactive nest, without eggs.

by the leithic basalt andsiltes and volcanic tuffs, with a NE-SO axis of $3.6 \mathrm{~km}$, and less than $1 \mathrm{~km}$ wide. The relief ranges from 0 to more than $300 \mathrm{~m}$ above sea level.

Skuasnests bowls were mapped in the field using a Garmin 76CSX navigation GPS (Global Positioning System), which is able to obtain a metric precision, using the single point positioning method [9], without posterior processing. The point sampled were transfered to the TrackMaker $^{\circledR}$ software and the resulting map was converted to the Drawing Interchange Format (.dxf). The points were overlapped with a base map proposed by [10], with help of Auto Cad software.

Skuas species were not differentiated because its classification is complicated due to morphological similarity, presence of mixed pairs, and hybridization. The descrip- tion and classification of the plant communities were based on the usual literature $[2,11,12]$. The identification of bryophytes was done based on the main floras for Antarctica [1,12-14]. The plant species samples were included in the Antartic Flora Collection of Federal University of Pampa Herbaria (HBI). The number of species sampled at each nest was tested for the statistical significance based in the One Sample T-test run in the Statistix 8 software.

\section{Results}

Were evaluated (61) nests, located on mosses field, rocks outcrops or, in some cases, on thawing channels. None comparative samples an analysis could been made with our nests with those sampled by [15], such these authors not show a GPS georeferrence about that Skuas nests found. Therefore overlapping the map images provide by these authors and that made in the presented study its possible estimates the nests occurrence in each grid, at $100 \times 100$ meters $\left(10.000 \mathrm{~m}^{2}\right)$ for both maps, in a total of 6.8 nests $\cdot$ ha $^{-1}$ sampled in 2010/2011 (Figure 2) against 5.4 nests $\cdot$ ha $^{-1}$ sampled 2004/2005.

On average 4, 2 plant species were found in each nest. In a single nest were observed eight species, the highest diversity found in the samples. Ten nests were found

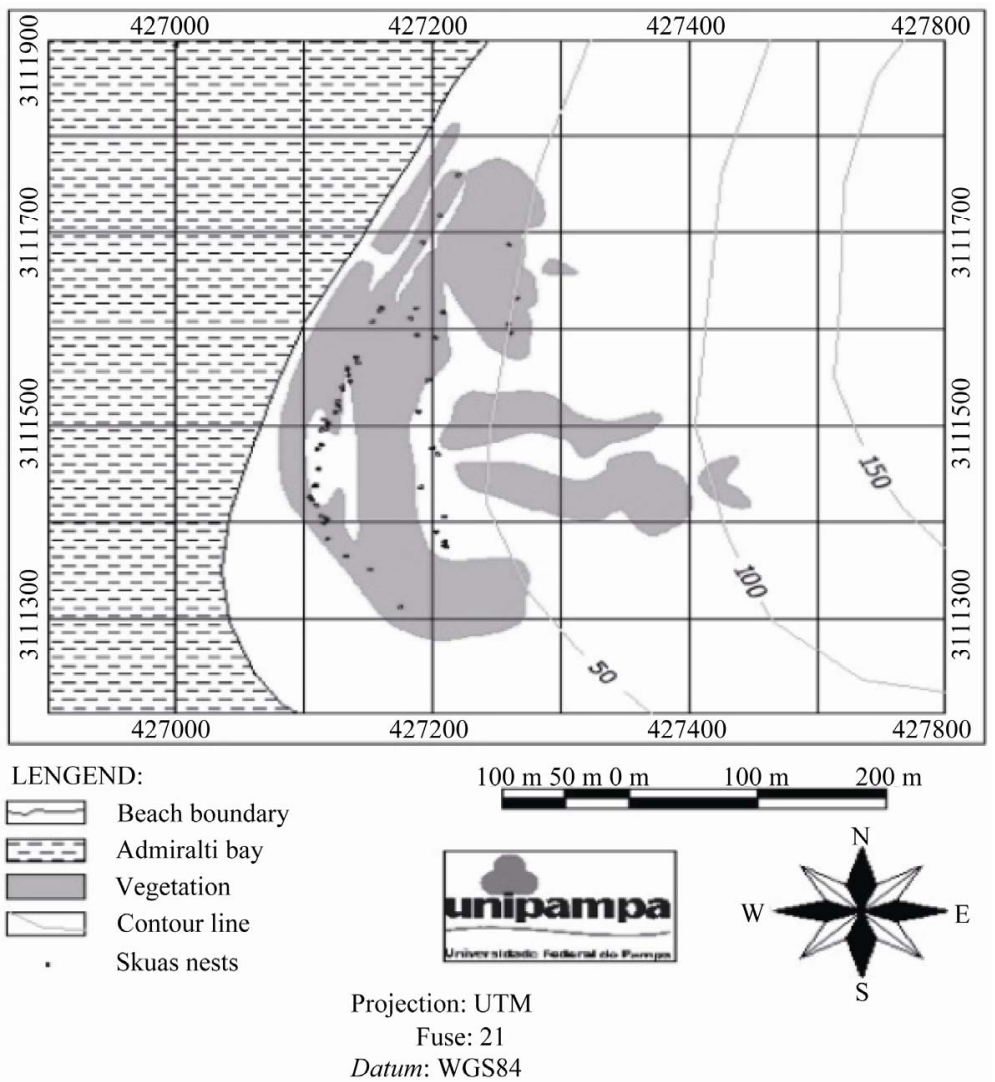

Figure 2. Skuas nest map distribution in the Hennequin Point, Admiralty Bay, King George Island. 
composed only by two species and a single nest a lone species was found (Figure 3). The mosses Sanionia uncinata (Hedw.) Loeske, Polytrichastrum alpinum (Hedw.) G. L. Smith Syntrichia magellanica (Mont.) R. H. Zander are the most frequent plant found in the Skua nests, followed by the antarctic grass Deschampsia Antarctica and for the terrestrial algae Prasiola crispa Lightfoot. For lichenized fungi the fruticolous lichen Usnea antarctica $\mathrm{Du}$ Rietz was the most representative species, followed by Spherophorus globosus (Huds.) Vain. Others moss species as Andreaeagainii Card., Bartramia patens Brid., Syntrichia filaris (Mül. Hal.) R. H. Zander and Chorisodontium aciphyllum (Hook $\mathrm{f}$. Wilson) Broth and the lichen species Ochrolechia frigida (Sw.) Lynge, Parmelia saxisatilis (L.) Ach., Pannaria hookeri (Borrer) Nyl., Sterocaulon glabrum (Müll. Arg.) Vain and Usnea aurantiacoatra (Jacq.) Bory are the less frequent species in the nests sampled (Figure 4).

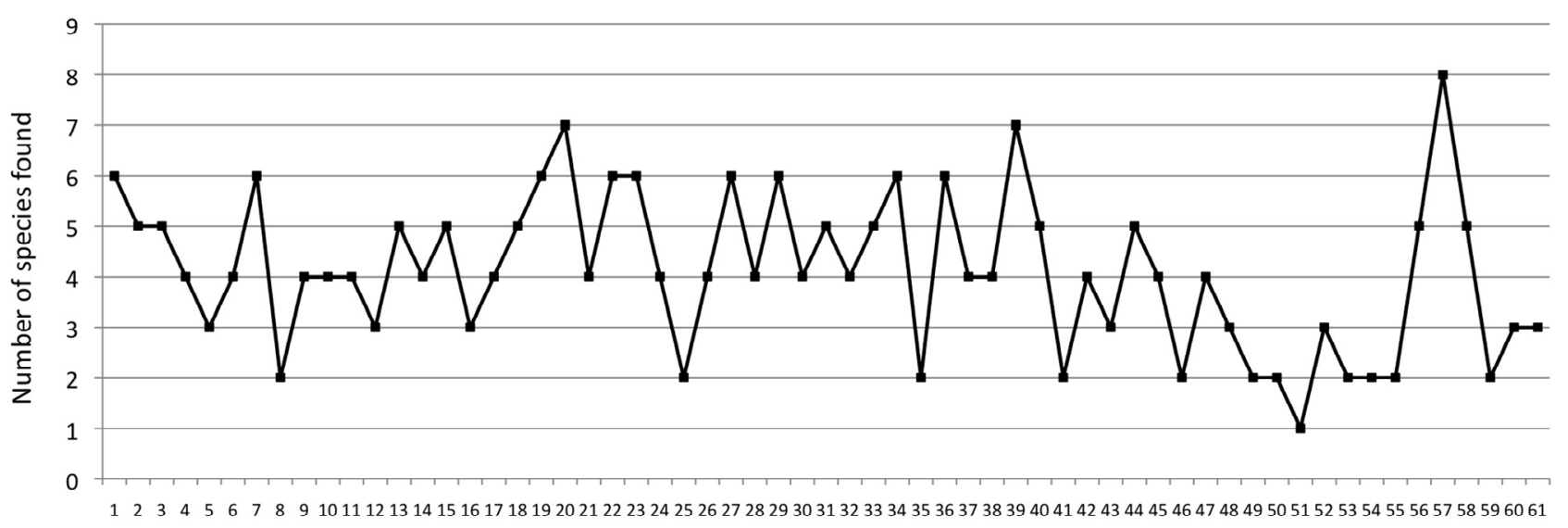

Skuas nest sampled in the Hennequin Point

Figure 3. Number of plant species per nests sampled at Hennequin Point, Admiralty Bay, King George Island. (p = 0.0472; Standart Desviation $=1.53$ ).

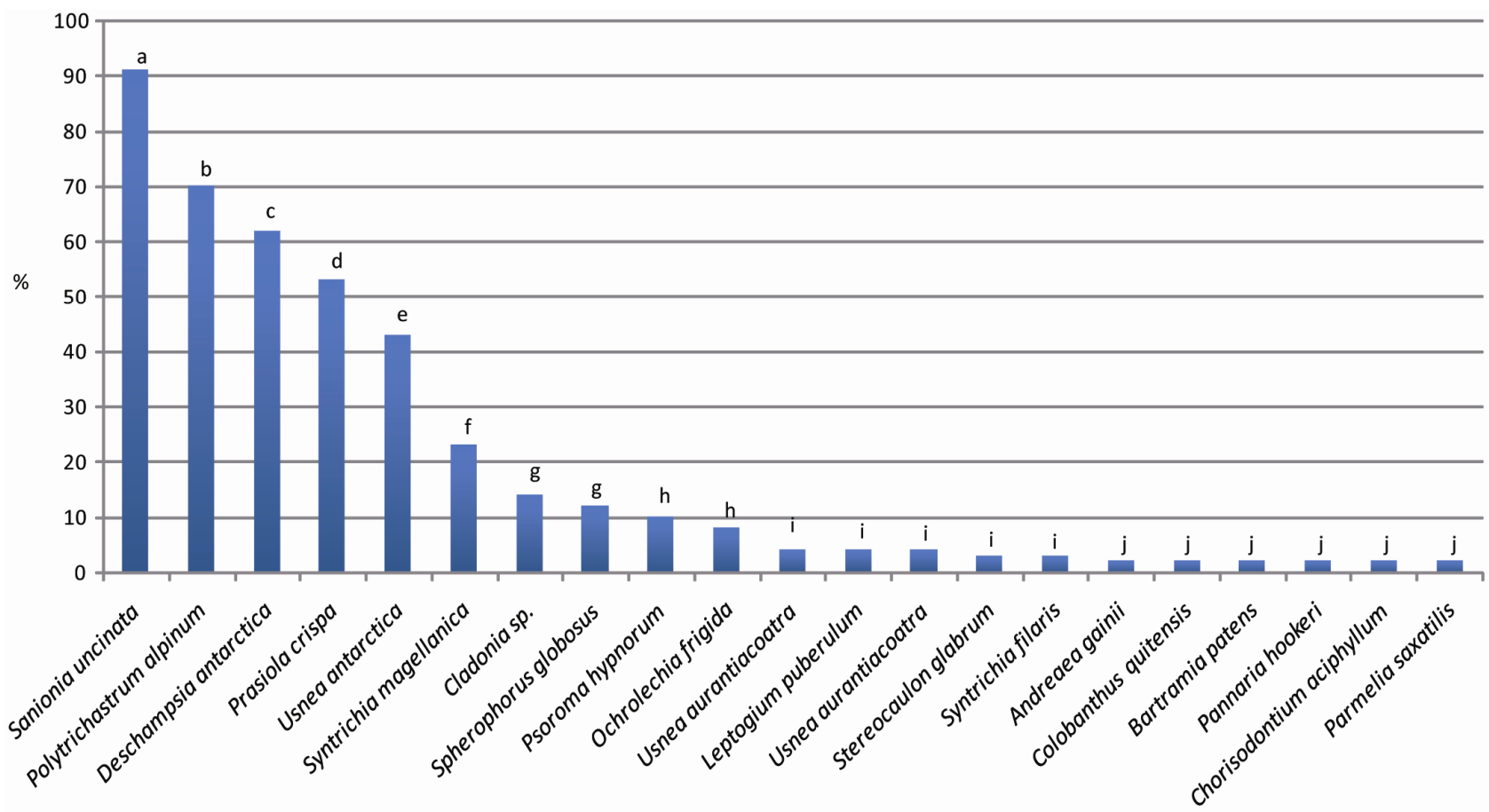

Species found in the Skuas nests

Figure 4. Number of occurrencesin per cent of each plants and lichen species sampled in the Skuas nests at Hennequin Point, Admiralty Bay, King George Island. (The same letters do not differs at the significance level $\mathbf{p}=\mathbf{0 . 0 5}$ ). 


\section{Discussion}

The global changes and consequent changes in Antarctic environment are a central point of recent studies. Some had reported the effect of climate changes on Antarctic and Sub-Antarctic species especially the increase in the predatory seabirds' populations. In Hennequin Point it was observed an increase of Skua pairs [15] what can be related to local glacial retraction $[16,17]$. The effect of this retraction was also studied in plant populations. There was an increase of the area where mosses and associated species, such as lichen, flowering plants and algae could colonize [2,18-20].

The main mosses found in the nests, occurs typically in plant communities at Admiralty Bay area [19], such Sanionia uncinata (Hedw.) Loeske and Polytrichastrum alpinum (Hedw.) G. S. Smith often occurring associated with a lichen species as Cladonia borealis S. Stenroos, Usnea antarctica Du Rietz, Leptogium sp. This species is considered the most abundant lichen associated to moss species, occurring together with others fruticolous species [18]. Furthermore, this species constitute the most visible talus when compared to other types such as crustosetallus. The occurrence of small lichen species in the nests could be because they were accidentally carried to the nest with mosses caught by Skuas.

Considering these sea bird species is the most abundant flying bird in Admiralty Bay, with 338 recorded nest sand at a density of 19.70 nests $\cdot \mathrm{km}^{-2}$, distributed in almost all ice-free areas [16]. During the breeding season of 1978/79 [3], a total of 50nests were found occupying a density of 2.91 nests $\cdot \mathrm{km}^{-2}$. Data comparison suggests an increase by $576 \%$ in the species population. The plant communities sizes were also change in some sites of Antarctica using by sea birds in the breeding season $[2,18$, 19], suggesting a closed relationship of the birds populations and the plant species.

Are observed an increasement of Skuas nests in Hennequin Point beach when compared with other bird evaluation in this area [15]. However, its not possible to test the significancy of these changes, such the comparation methods used does not applies for these proposes. The number of Skuas nests in the study area increasefrom 5.4 nest $\cdot$ sha $^{-1}(2004 / 2005)$ to 6.8 nest $\cdot$ sha $^{-1}$ (2010/ 2011). It also observed an side-by-side occurrences of birds nests, being the higher density found at the plateau close to beach (Figure 2) where the most plants communities biomass are also established.

Two of the tree main plant species found at the nests were also registered in a similar approach at Antarctic Peninsula [8], such Polytrichastrum alpinum and Deschampsia antarctica. Taking into consideration that the dominance of species can vary among different places at Antarctica, there might be a certain selection of those species. Among other variables, nests characteristics can be important to Skuas reproductive success [5,21-24]. Taking it into consideration it is important to continue researches in order to evaluate if different nests components could influence Skuas reproductive success.

\section{Acknowledgements}

The authors thank the Brazilian National Council of Scientific Research-CNPq (process 574018/2008 e 314664/ 2009-2), FAPERJ (process E-26/170.023/2008) and MMA/ MCT/PROANTAR for the financial support.

\section{REFERENCES}

[1] J. Putzke and A. B. Pereira, "The Antarctic Mosses with Special Reference to the South Shetland Islands,” EDULBRA, Canoas, 2001.

[2] A. B. Pereira and J. Putzke, "Floristic Composition of Stinker Point, Elephant Island, Antarctica," Korean Journal of Polar Research, Vol. 5, No. 2, 1994, pp. 37-47.

[3] B. Jablonski, "Distribution, Abundance and Biomass of a Summer Community of Birds in the Region of the Admiralty Bay (King George Island, South Shetland Islands, Antarctica) in 1978/1979," Polish Polar Research, Vol. 7, 1986, pp. 217-260.

[4] D. F. Parmelee, "The Hybrid Skua: A Southern Ocean Enigma,” Wilson Bulletin, Vol. 100, 1988, pp. 345-356.

[5] M. S. Ritz, S. Hahn, T. Janicke and H.-U. Peter, "Hybridization between South Polar skua (Catharactamaccormicki) and Brown skua (C. antarcticalonnbergi) in the Antarctic Peninsula Region,” Polar Biology, Vol. 29, No. 3, 2005, pp. 153-159. doi:10.1007/s00300-005-0034-0

[6] A. P. B. Carneiro, M. Polito, M. Sander and W. Z. Trivelpiece, "Abundance and Spatial Distribution of Sympatrically Breeding Catharacta spp. (Skuas) in Admiralty Bay, King George Island, Antarctica,” Polar Biology, Vol. 33, No. 5, 2010, pp. 673-682. doi:10.1007/s00300-009-0743-X

[7] R. W. Burton, "Breeding Biology of the Brown Skua, Catharacta skua lönnbergi (Matheus) at Signy, South Orkney Islands,” British Antarctic Survey Bulletin, Vol. 15, 1968, pp. 9-28.

[8] R. D. Quintana, V. Cirelli and O. Benitez, "Nest Materials of skuas (Catharacta spp.) and Kelp Gulls (Larusdominicanus) at Cierva Point, Antarctic Peninsula,” Notornis, Vol. 48, 2001, pp. 235-241.

[9] M. T. Matsuoka, D. M. Soares, S. F. Souza and M. S. Veronez, "Análise da Aplicação de Receptor GPS de Navegação No Posicionamento Relative Estático de Linha-Base Curta," Gaea-Journal of Geoscience, Vol. 4, No. 2, 2008, pp. 88-93.

[10] J. Aragony-Neto, J. C. Simões, U. F. Bremer and N. Dani, "Perspectivas para o Gerenciamento Ambientalda Baía do Almirantado, Ilha Rei George, Antártica,” Revista do Departamento de Geografia, Vol. 15, 2002, pp. 91-99. 
[11] R. I. Lewis-Smith and C. H. Gimingham, "Classification of Cryptogamic Communities in the Maritime Antarctic," British Antarctic Survey Bulletin, Vol. 33-34, 1976, pp. 89-122.

[12] J. Redón, “Líquenes Antárticos,” Instituto Antártico Chileno (INACH), Santiago de Chile, 1985.

[13] R. Ochyra, "The Moss Flora of King George Island Antarctica,” Polish Academy of Sciences, Cracow, 1998.

[14] D. O. Øvstedal and R. I. Lewis-Smith, "Lichens of Antarctica and South Georgia-A Guide to Their Identification and Ecology," Studies in Polar Research, Cambridge University Press, 2001.

[15] E. S. Costa and M. A. S. Alves, "The Breeding Birds of the Hennequin Point: An Ice-Free Area of Admiralty Bay (Antarctic Specially Managed Area), King George Island, Antarctica,” Revista Brasileira de Ornitologia, Vol. 16, No. 2, 2008, pp. 137-141.

[16] M. Sander, A. P. B. Carneiro, T. C. Balbao, S. R. Bays, E. S. Costa, N. E. Mascarello, T. D. Olivaand and C. R. Santos, "Status and Trends of Antarctic Seabirds at Admiralty Bay, King George Island,” Polar Forschung, Vol. 75, No. 2-3, 2005, pp. 145-150.

[17] V. Siegel, "Distribution and Population Dynamics of Euphausia superba: Summary of Recent Findings,” Polar Biology, Vol. 29, No. 1, 2005, pp. 1-22. doi:10.1007/s00300-005-0058-5

[18] F. C. Victoria, M. P. Albuquerque and A. B. Pereira, "Lichen-Moss Associations in Plant Communities of the
Southwest Admiralty Bay, King George Island, Antarctica," Neotropical Biology and Conservation, Vol. 1, 2006, pp. 84-89.

[19] F. C. Victoria, A. B. Pereira and D. P. Costa, "Composition and Distribution of Moss Formation in the Ice-Free Areas Adjoining the Arctowski Region, Admiralty Bay, King George Island, Antarctica,” Iheringia, Vol. 64, No. 1, 2009, pp. 81-91.

[20] F. C. Victoria and A. B. Pereira, "Índice de Valor Ecológico (IES) Como ferramenta para estudos fitossociológicos e conservação das Espécies de Musgosna Baia do Almirantado, Ilha Rei George, Antártica Marítima,” Oecologia Brasiliensis, Vol. 11, 2007, pp. 50-55.

[21] E. Trillmich, "Feeding Territories and Breeding Success of South Polar Skuas,” Auk, Vol. 95, 1978, pp. 23-33.

[22] W. Trivelpiece and N. J. Volkman, "Feeding Strategies of Sympatric South Polar Catharacta maccormicki and Brown Skua C. lönnbergi,” Ibis, Vol. 124, No. 1, 1982, pp. 50-54. doi:10.1111/j.1474-919X.1982.tb03740.x

[23] F. Pezzo, S. Olmastroni, S. Corsolini and S. Focardi, "Factors Affecting the Breeding Success of the South Polar Skua Catharacta maccormicki at Edmonson Point, Victoria Land, Antarctica,” Polar Biology, Vol. 24, No. 6, 2001, pp. 389-393. doi:10.1007/s003000000213

[24] S. Hahn and H-U. Peter, "Feeding Territoriality and the Reproductive Consequences in Brown Skuas Catharacta antarctica lonnbergi," Polar Biology, Vol. 26, No. 8, 2003, pp. 552-559. doi:10.1007/s00300-003-0522-z 